\title{
Immigrants and Poverty, and Conditionality of Immigrants' Social Rights
}

\author{
Beatrice Eugster
}

\begin{abstract}
It is not only immigration and the incorporation of immigrants into the society that serve as challenges for post-industrialised countries, but also rising inequality and poverty. This article focuses on both issues and proposes a new theoretical perspective on the determinants of immigrant poverty. Building on comparative welfare state research and international migration literature, I argue that immigrants' social rights - here understood as their access to paid employment and welfare benefits - condition the impact which both the labour market and welfare system have on immigrants' poverty. The empirical analysis is based on a newly collected dataset on immigrants' social rights in 19 advanced industrialised countries. The findings confirm the hypotheses: more regulated minimum wage setting institutions and generous traditional family programs reduce immigrants' poverty more strongly in countries where they are granted easier access to paid employment and social benefits.
\end{abstract}

Keywords: Comparative welfare state research, immigrants, poverty, social rights, multilevel analysis 


\section{Introduction}

Although immigration and ethnic diversity have become an integral part of advanced industrialised societies, these countries differ in terms of immigrants' socio-economic incorporation. The recent immigration and refugee crisis in Europe has continued to accelerate the ongoing debate. This debate is boosted at a time when inequality has risen in most advanced industrialised countries (OECD, 2015a). This article deals with how national socio-economic regulations differ in incorporating immigrants and whether these regulations affect immigrants at the margins of society.

From a societal perspective, the ability of countries to incorporate immigrant minorities is also relevant for the non-immigrant majority, as such redistribution might not only reduce poverty, but also countervail socio-economic differences between various segments in the population. In turn, welfare state efforts shape public attitudes towards redistribution and poverty as well as welfare abuse and dependency. In the end, they affect social solidarity and cohesion within a society (Banting and Kymlicka, 2006). Regarding the salience of immigration in advanced industrialised countries, it is thus central to understand whether and how nation-states reduce immigrants' poverty.

While extensive research in the international migration literature provides insights into the socio-economic incorporation of immigrants, the comparative welfare state literature has studied various mechanisms to explain cross-national variations in poverty. However, scholarly calls for bringing both literature strands together have hardly been addressed (e.g. Freeman, 2004). Generally speaking, research on immigrants' socio-economic incorporation neglects the role of macro-level factors such as labour market and welfare state institutions. Instead, most studies focus on migrant-specific factors such as immigrants' rights and immigration-related policies (e.g. Koopmans et al., 2005) or the impact of language proficiency and ethnic organisations on immigrants' socio-economic outcomes (e.g. Kesler, 
2015; Van Tubergen et al., 2004). By contrast, welfare state scholars have only started to address immigration in their theoretical approaches and rarely include immigrants in their empirical analysis, e.g. the growing literature on the 'dualisation' of labour markets and welfare states (see contributions in Emmenegger et al., 2012).

Two contributions stand out that link welfare states to immigrants' poverty. Sainsbury's research (2012) places emphasis on immigrants' social rights and the importance of immigration regimes. Corrigan (2014) points to the conditionality of securing a legal status, or more precisely getting long-term residency status. The idea that immigrants are not a homogenous group but that various forms or types of legal statuses of immigration exist is not only central in both contributions, but also for this article (e.g. labour migration, family reunification, even permanent residents; see Morris, 2003). Sainsbury $(2006,2012)$ argues and exemplarily shows that each of these immigration groups are entitled to different social rights, while Corrigan (2014: 224) relates a 'secure enjoyment of social rights and welfare entitlement $[\ldots]$ to those holding long-term residency (LTR) status', albeit taking for granted that full social rights accrue from LTR status.

Building on these studies, I assess two assumptions in the literature, namely that immigrants' and citizens' social rights hardly differ, and that the main division is between permanent and temporary immigrants. By drawing specific attention to social rights of different immigration groups and related mechanisms affecting their poverty, I provide not only a novel analytical framework that links immigrants' social rights to the labour market and welfare system but also test it by using a newly collected dataset on immigrants' social rights in 19 advanced industrialised countries.

The article is structured as follows: In the next section, I introduce the analytical framework on determinants of immigrants' poverty and discuss why it is important to consider immigrants' social rights. After describing the data sources and operationalisation, 
the main findings and alternative explanations for the unexplained part of cross-national variations in immigrants' poverty are presented.

\section{From social rights and poverty to immigrants}

The framework departs from the comparative welfare state literature, which identifies the welfare state as the major determinant of poverty (see Brady, 2009 for an extensive literature review). Welfare states grant citizens social rights that, in turn, give access to social programs. Welfare states thus directly influence poverty by means of social policies targeting those in need. At least three social programs are considered to be the most important to alleviate poverty (Huber and Stephens, 2001: 108).

First, unemployment programs aim to compensate workers and families for the loss of market income in precarious situations beyond their individual control. The empirical evidence looking at the effect of unemployment compensation on poverty partly supports this claim. For example, Bäckman's (2009) analysis across 16 Western countries between 1980 and 2000 indicates that more generous unemployment insurance has a poverty-reducing effect. However, Scruggs and Allan's study (2006) finds that the generosity of sickness and pension benefits are better predictors of working-age and old-age poverty than unemployment benefits.

Second, family-related programs contribute to poverty reduction either by augmenting the family income or by promoting a mother's paid employment, which is increasingly understood as a component of the anti-poverty strategy (Gornick et al., 1997: 65). Accordingly, two types can be distinguished: traditional family support (e.g. cash and noncash benefits and tax allowances) and dual-earner or work-family policies (e.g. paid or unpaid parental leave, caregiver allowances and support for subsidised or state-provided external childcare). Concerning dual-earner programs, however, it has been argued that they produce 
Matthew effects, i.e. that they tend to benefit higher-income families. Better-educated mothers are more likely to participate in the labour market and thus to make use of these programs compared to lower-educated mothers (Cantillon, 2011). Even if the Matthew effect can be observed notably regarding parental leave (for a detailed analysis see van Lancker, 2014), empirical studies so far show that both types contribute to poverty reduction (Bäckman and Ferrarini, 2010; Misra et al., 2007, 2012).

Finally, social assistance aims to ameliorate the living standard of those in the most precarious financial situations by providing a guaranteed minimum income. Therefore, more generous social assistance is expected to reduce poverty. However, it has been contested in the literature whether targeting those in need is the most efficient way to fight poverty. Opponents, for example, point to the stigma recipients of means-tested benefits are exposed to and thus the reluctance to rely on them. In this context, Korpi and Palme (1998) refer to the paradox of redistribution that there is a trade-off between the degree of low-income targeting and redistribution. Following their argument, an expansion of non-means-tested programs, which enjoy higher support among the electoral constituency, has a positive side effect on means-tested programs and thus poverty alleviation via a bigger redistributive budget size. Yet, recent research shows that the relation between targeting, universalism and redistribution has faded away since the mid-1990s (Kenworthy, 2011; see Marx et al., 2013 for a thorough analysis of the redistribution paradox). According to Kenworthy (2011: 56) in the mid-2000s universalism of social transfers did no longer affect the size of the redistributive budget. Marx and his colleagues (2013) corroborate this result and find only for family benefits that less targeting goes along with higher redistribution. Moreover, the decomposition analysis shows that higher targeting of social assistances goes along with higher redistribution. But empirical evidence more specifically on poverty so far suggests that means-tested social benefits fail to 
reduce poverty as compared to non-means-tested social benefits, at least for the period between 1970 and 2000 (e.g. Moller et al., 2003; Sainsbury and Morissens, 2002).

In addition to social policies, welfare states can also reduce poverty through the labour market by affecting employment opportunities and earnings (Brady 2009; Esping-Andersen, 1990; Huber and Stephens, 2001; Lohmann, 2009; Moller et al., 2003). Two types of labour market institutions ensure that fair wages are paid and thus affect poverty. First, concerning wage setting institutions, the standard argument goes that higher centralisation (i.e. the level where wage negotiations take place, e.g. firm, industry or national level) and coordination (i.e. actors involved in the bargaining process, e.g. unions, employer associations) lead to wage compression. Centralised/coordinated wage setting reduces the spread of inter-firm and inter-sector earnings by including a higher share of firms and sectors in a single wage agreement (Pontusson et al., 2002: 289). The scant empirical findings so far suggest that countries with more regulated wage setting mechanisms not only exhibit lower wage dispersion and income inequality, in particular at the bottom end (Pontusson et al., 2002; Wallerstein, 1999), but also lower levels of poverty (Lohmann, 2009).

Second, the effect of statutory minimum wages, as a particular form of wage setting, on poverty is also contested in the literature (see Addison and Blackburn, 1999). While minimum wages raise earnings of low-paid workers and thus reduce poverty, they might affect employment negatively by destroying low-paid jobs or hindering the creation of new positions if minimum wages are set above the productivity level of workers (e.g. OECD, 1998). This is especially relevant in countries that rely heavily on social security because nonwage level costs, e.g. contributions paid by employers, cannot be shifted to employees (Eichhorst and Marx, 2012). Empirical findings are mixed, but suggest that these effects are relatively modest (see Betcherman, 2012 for a review). 
Social rights have to be defined in a broader sense as going beyond access to redistributive programmes as the labour market and welfare system are closely related to each other. Both affect individuals' decision to participate in the market and thus a country's prevailing income and wage distribution (Esping-Andersen, 1990; Huber and Stephens, 2001). On the one hand, labour market participation entitles individuals to social rights by paying social security contributions. On the other hand, the very existence and generosity of social programs affect individuals' decisions to enter the labour market (e.g. availability of childcare or tax system, see Esping-Andersen, 1999). Therefore, social rights, for the purpose of this article, include not only rights to welfare benefits but also the right to paid employment. The latter is intrinsically linked to classic social rights through labour market participation, as discussed above.

The necessity for an encompassing definition of social rights is particularly important when immigrants are considered. As feminist scholars argue, although women have full access to the labour market and paid employment, at least in formal terms, they cannot exercise their right, e.g. due to their responsibilities related to care and domestic work (see Orloff, 1993). This argument not only holds for immigrants but is even of particular importance. Here, it is not primarily about whether immigrants can practice their formal rights or not, but whether they are granted these rights in the first place. Certain immigrant groups simply lack the formal right to paid employment, such as family members of migrant workers. Indeed, immigrants and citizens' rights vary as the international migration and citizenship literature shows (e.g. Aleinikoff and Klusmeyer, 2002; Brubaker, 1989; Soysal, 1994). Thus, the implicit assumption of the comparative welfare state literature that immigrants - i.e. various immigration categories - have the same social rights as citizens has to be further scrutinised. Nevertheless, the poverty reducing mechanisms through the labour market and welfare system discussed above might also apply to immigrants, though under specific 
conditions. In order to specify these conditions, the framework draws on migration literature, which has extensively explored how nation-states incorporate foreigners into the country.

Two central insights from the migration literature are essential for this framework: first, the distinction between immigration policies governing the admission and selection of foreigners into the country and integration policies affecting immigrants once they are settled in the country (the latter comprises immigrants' social rights; see Hammar, 1985) and, second, the need to differentiate between several immigration (or entry) categories (Brubaker, 1989; Morris, 2003). Among the most important immigration categories identified in the literature are labour migrants, refugees and asylum seekers, family members and permanent residents (see also Helbling et al., 2016). ${ }^{1}$ Both points are related to each other. Through immigration policies, states can regulate immigration inflow of each immigration category separately by imposing quotas or specifying conditions that immigrants have to meet in order to legally settle in the country. ${ }^{2}$ Depending on the specific immigration categories, immigrants are entitled to different social, economic, cultural and even political rights.

Research on citizenship agrees that the correspondence between nationality and citizenship rights is blurred (for a literature review, see Bloemraad et al., 2008). The main division in a country's resident population is not between nationals and non-nationals, but holders of different types of residence permits, specifically between permanent and temporary residents (Aleinikoff and Klusmeyer, 2002; Brubaker, 1989: 156; Hammar, 1990; Sainsbury, 2006, 2012). ${ }^{3}$ As these authors contend, rights of citizens and immigrants, at least permanent and legal residents, hardly differ. The reason is that permanent residence comes along with almost unrestricted access to the labour market, education, business, social programs and civil rights, if not necessarily political rights (Hammar, 1990; Layton-Henry, 1990: 189; Soysal, 1994). This assumption that social rights vary between immigration categories is central for the framework. 
Embedding immigrants' social rights into the labour market and welfare system

Combining both strands of literature, I expect that social rights, i.e. immigrants' access to paid employment and social programs, condition the impact of both the labour market and welfare state on immigrants' poverty (see Figure 1). More specifically, labour market regulations reduce immigrants' poverty but this effect is conditional on whether immigrants have access to paid employment in the first place. Put simply, once immigrants are granted access to the labour market and pursue paid employment, labour market institutions are expected to affect them in the same way as they affect the native working force. This simplified argument obviously neglects that not only formal labour market access but also informal practices matter, such as migrant networks. ${ }^{4}$ Especially important is labour market discrimination which can be understood as the differential treatment of persons or groups based on specific characteristics (e.g. nationality, ethnicity, religion, age and gender) either due to prejudices (the affective component of attitudes) and/or stereotypes (related to the lack of adequate information and also known as statistical discrimination; see Pager and Shepard, 2008). Labour market discrimination might affect immigrants' poverty through lower wages and/or access to employment, e.g. lower callback rates and wage offers in the hiring process (Dancyngier and Laitin, 2014). Despite the difficulties to measure discrimination, evidence based on surveys, field experiments and statistical analysis shows that immigrants experience discrimination across OECD countries, although wage and employment disparities have diminished over time and depend on the type of job as well as the minority group studied (see Bassani and Saint-Martin, 2008). Bearing this in mind, this study focuses above all on the impact of the institutional setting and therefore whether immigrants are granted formal labour market access. Thus, I expect that the poverty-reducing impact of stricter labour market 
regulations on immigrants' poverty is conditional on the inclusiveness of social rights, here whether immigrants have access to paid employment.

\section{[insert Figure 1]}

The same argument can be made for the welfare system. More generous social programs are expected to be associated with lower poverty as they augment or replace the income of various segments of the population, including those in need, families and the unemployed. But immigrants living in a country with generous social programs might not be, per se, better off than their counterparts living in a country with a lean welfare state. Instead, whether generous welfare state institutions have a poverty-reducing effect depends on whether immigrants have access to social programs. Consequently, I hypothesise that the povertyreducing impact of a generous welfare system on immigrants' poverty is conditional on the inclusiveness of social rights, here whether immigrants have access to social programs.

Additionally, the framework also incorporates alternative explanations for immigrants' poverty. First, it considers the composition of the immigrant population living in the country, which is related to a country's prevailing immigration policies. In general, immigrants that were selected based on their skills and labour demand might have fewer difficulties integrating into the market and society compared to those migrating for humanitarian or personal reasons, e.g. refugees and family members. Labour migrants might have more time to invest in the transferability of their skills while still in their country of origin (see Bauer et al., 2000). Therefore, I expect that countries with higher shares of immigrants from industrialised countries have lower immigrant poverty. Second, the economic situation of a country, in particular higher economic growth and lower unemployment are both are both expected to reduce poverty (Bäckman, 2009; Brady, 2009; Gundersen and Ziliak, 2004; Moller et al., 2003). Finally, I also control for the impact of socio-demographic factors at the 
individual-level. As previous studies show, human capital in terms of education and skills as well as the composition of households (number of children and elderly) and employment pattern of household members, including whether they work in atypical employment (e.g. part-time or temporary-contract employment), affect poverty (e.g. Brady et al., 2009; Kesler, 2015; Lohmann, 2009).

\section{Data, operationalisation and methods}

The analysis includes 19 advanced industrialised countries (Australia, Austria, Belgium, Canada, Denmark, Finland, France, Germany, Greece, Ireland, Italy, Netherlands, Norway, Portugal, Spain, Sweden, Switzerland, the United Kingdom and the United States) and relies on data from different household income surveys for the year $2007^{5}$ ('EU Statistics on Income and Living Conditions (EU-SILC)' for 16 European countries, the 'Household, Income and Labour Dynamics in Australia Survey (HILDA)', the Canadian 'Survey of Labour and Income Dynamic (SLID)' and the 'Current Population Survey (CPS)' for the United States). These household surveys provide insights into the immigrant background, i.e. whether household members are foreign-born or not $^{6}$, as well as detailed information on income composition of households. The Luxembourg Income Studies (LIS) terminology concerning factor income and disposable household income after taxes and transfers has been used to make the EU-SILC and national household income surveys comparable. ${ }^{7}$

Following comparative research on poverty (e.g. Brady et al., 2009; Korpi and Palme, 1998), poverty rates are defined in relative terms as the share of households whose income is below the poverty line, here defined as $50 \%$ of a country's median income and adjusted for the family size by using the modified OECD equivalence scale. ${ }^{8}$ The analysis is limited to the working-age population (21-59), as this group is affected by both labour market regulations and social programs. 
The first poverty measure, used for the labour market model, is poverty based on market income before taxes and transfers, which includes earnings, salaries from self-employment, and income from cash property. The second poverty measure for the welfare model, poverty reduction, refers to a household that escapes poverty, i.e. that is defined as poor based on the market income but lifted out of poverty when taking taxes and social transfers into account (see Lohmann, 2009).

The income surveys are also used to assess the socio-economic characteristics such as education (ISCED educational level) ${ }^{9}$, skills (ISCO 88 classification, NAICS for Canada and SOC for the US), labour market participation (main activity status during year), atypical employment (incl. part-time, part of the year, temporary contract, family worker and unemployed, see Häusermann and Schwander, 2012), self-employment, and number of children and elderly. Since the socio-demographic characteristics of all household members are considered (see also Kesler, 2015), I proceed as follows: First, adults are identified based on the age (above 25 years economically active aged 18-24) and the family composition. Second, the immigrant background and socio-economic characteristics are assigned to each adult, which are, finally, aggregated to the household level by combining the different values of all adult household members. For example, if a household consists of two adults, one with a primary education (ISCED 1) and the other with an upper secondary education degree (ISCED 3), the household is coded as 'mixed, low (ISCED 0-4)'.

\section{Immigrants' access to paid employment and social programs}

To assess social rights of immigrants across countries, a newly collected dataset has been used. It builds on previous research (e.g. Aleinikoff and Klusmeyer, 2002; North et al., 1987 cited in Brubaker, 1989: 159; Ruhs, 2013; Soysal, 1994) and provides a comparative overview of access of different immigration categories to social programs and paid 
employment. To operationalise immigration categories, I rely on the type of permits issued to immigrants. The four immigration categories included in this study are: (1) holders of temporary residence permits issued for the purpose of work (hereafter: labour migrants), (2) family members of labour migrants, (3) holders of permanent residence permits (hereafter: permanent residents), and (4) family members of permanent residents. ${ }^{10}$

The operationalisation of immigrants' social rights as access to paid employment distinguishes four different categories (see also Ruhs, 2013). For labour migrants these are:

0: $\quad$ employment is tied to a specific employer,

1: change of employment is possible, but requires a new work permit,

2: workers are allowed to change employment within a specific sector, occupation or region,

3: $\quad$ migrant workers have full access as nationals.

For the remaining three immigration categories I distinguish whether an immigration category:

0: $\quad$ is not permitted to work,

1: $\quad$ has to apply for a working permit,

2: $\quad$ gets unlimited working rights after a certain period or accelerated procedure (e.g. no labour market test)

3: $\quad$ has full access as nationals.

Regarding immigrants' social rights in terms of access to welfare programs (unemployment, family-related and social assistance), the indicators combine two factors that have been shown to be important by different authors: access of specific immigration categories and the length of residence (see Aleinikoff and Klusmeyer, 2002; North et al., 
1987; Soysal, 1994). The former considers who, based on the residence permit, has access and the latter for how long immigrants are prohibited to access specific social programs, primarily universal or means-tested programs that do not require a previous period of contribution (e.g. Australia where permanent residence permits are granted from the beginning of the stay). But length of residence is also applicable to contributory social programs, where a certain time of previous employment is required. The threshold for the length of residence is set at five years because in the majority of the countries this is the required time to be eligible for a permanent residence permit. For the contributory social programs, a lower threshold of 52 weeks is selected. The main reason is that the loss of their jobs affects their renewal of their permits for immigrants with limited residence permits (usually 1 year). The categories are:

0: no access

1: $\quad$ waiting period $\geq 5$ years or $\geq 52$ weeks of employment

2: $\quad$ waiting period $<5$ years or $<52$ weeks of employment

3: employment

4: full access

For the coding of immigrants' social rights, relevant national immigration and social security laws were identified using secondary sources (country notes in Huddleston et al., 2011; IOM, 2009; MISSOC, 2007; OECD, 2007). For the access of the four immigration categories to social programs, the data were collected first at the most specific level and then aggregated to one of the four broader social programs - unemployment compensation, traditional family support, dual-earner support and social assistance - for each immigration category and all immigration categories together. The final indices have been rescaled from 0 to 3 or 4 to range between 0 and 1 . Whenever possible the national legislation as of 1 January 2007 is considered. 


\section{Labour market regulations and social programs}

The labour market regulations are operationalised using different indicators related to wage bargaining institutions, i.e. Kenworthy's (2001) index of coordination of wage bargaining and degree of government intervention in wage bargaining, and to statutory minimum wages, i.e. a minimum wage setting index combining information on different actors and the level of application (sectoral or national) as well as the share of the minimum wage in percentage of the median wage, obtained from the OECD.Stat (OECD, 2015b). The information for the institutional variables is taken from Visser's (2011) ICTWSS dataset.

Welfare state generosity is measured as follows. Unemployment programs are operationalised using the average of the net replacement rates for households with earnings $67 \%$ of the average wage (AW). Traditional family benefits are measured as average benefits in $\%$ of the AW for households earning $67 \%$ (or 134\%) of the AW. Both indicators were calculated using the dataset accompanying the OECD benefits and wages report for 2007. Dual-earner programs are assessed by the generosity of parental leave, i.e. the full-rate equivalent paid maternity, paternity and parental leave, accessible in the OECD Family Database (OECD, 2015b). Finally, social assistance refers to the share of minimum income protection for households of the AW available in Nelsons' (2007) Social Assistance and Minimum Income Protection Interim Data Set.

The control variables at the macro-level include the share of foreigners born in industrialised countries (OECD, 2015b) as well as GDP growth (5-year average) and unemployment rate (\% of labour force), both indicators from Armingeon et al. (2015) Comparative Political Data Set.

\section{Methodology}


Multilevel models with random intercepts using maximum likelihood estimations are used. Such models allow accounting for the hierarchical structure of the data, where individuals (level-1 observations, here households) are nested within a contextual unit (level-2 units, here countries; see Snijders and Bosker, 2012). Although the literature agrees that 19 level-2 units should be sufficient to estimate meaningful and significant multilevel models (Rabe-Hesketh and Skrondal, 2012), the subsequent models aim to minimise the number of country-level variables. ${ }^{11}$ To facilitate interpretation, all continuous variables have been centred at their means.

\section{Results}

Immigrants' social rights across countries

Looking at immigrants' access to paid employment, Figure 2 shows that it is relatively unrestricted across all countries. Finland, France and Britain are among the most inclusive countries. All grant permanent residents and family members of both permanent residents and labour migrants full access to paid employment. On the bottom, Austria, Ireland and the USA score relatively low mainly due to the restrictions they put on labour migrants and family members of immigrants in general (see also IOM, 2009).

\section{[insert Figure 2]}

Turning to specific immigration categories, permanent residents in general are granted unrestricted access to paid employment, which is also the case for their family members. Exceptions are Austria and Ireland as well as Greece and Spain where migrant family members have to apply for a work permit, though only during the first year and without being subject to a labour market test. By contrast cross-national variations can be found for temporary immigrants and their family members. 
Two major practices for recruiting labour migrants can be observed. ${ }^{12}$ The first practice links the work permit to employment with a specific employer. According to Ruhs (2013: 74), over $90 \%$ of temporary migration programs required a job offer, while just over a half of all programs further required a labour market test. A second practice is also common; to allow labour migrants to pursue any job, albeit limited to a specific sector, occupation or region (e.g. France, Germany, Greece, Spain, and Britain). This alternative practice also targets higher skilled immigrants (e.g. Canadian Federals Skilled Worker program, the skilledindependent regional visa in Australia, or the Dutch 'kennismigranten' migrant workers' scheme).

However, unrestricted access to employment does not depend on obtaining a permanent residence permit. Several countries allow specific labour migrants unrestricted access after being employed for a specific time period (e.g. after one year in Spain), which is often accompanied by an unlimited residence permit (e.g. in Belgium after four years). In contrast to the permanent residence permit, this unlimited residence permit does not entitle additional rights (e.g. protection from expulsion). Nevertheless, whether a sponsor has a limited or unlimited residence permit affects his/her family members' access to paid employment.

\section{[insert Figure 3]}

Figure 3 presents immigrants' access to social programs by type and country. Concerning the index on immigrants' access to unemployment programs, Finland and Ireland are among the most inclusive countries towards immigrants as they combine unemployment insurance and assistance. Denmark, Austria, Belgium, Switzerland and Italy are the most exclusive, requiring at least 52 weeks of previous social security contributions. The range, when compared to the other types of programs, is relatively small because all the countries either require a previous employment record or make access dependent on a waiting period. This is 
also the case regarding immigrants' access to dual-earner programs. Sweden together with Italy and the Netherlands are the most inclusive countries and all grant access to parental leave based on legal stay or previous employment rather than previous contributions. At the other end, we find the USA where no national parental leave scheme is available. Crossnational variation is not only considerably larger for traditional family benefits, but also the ranking of the countries changes. Austria is among the six countries that grant immigrant families full social rights as compared to the USA and Australia. Finally, several countries grant immigrants full access to social assistance, namely Norway, Sweden, the Netherlands, Italy and Portugal. By contrast, the most exclusive countries are the USA and Switzerland, together with Greece where no national social assistance program exists.

As the results show, immigrants' social rights do not neatly fit with Esping-Andersen's (1990) classic typology of welfare regime. Nevertheless, a certain clustering of countries can be observed: Nordic countries, except Denmark, tend to grant immigrants easier access to social programs, while immigrants' access is rather restricted in Anglo-Saxon countries such as the USA and Britain. However, more detailed analysis demonstrates that the basis of entitlement to social programs (universal, contribution-based or means-tested) rather than the type of welfare regime or social program is decisive regarding whether or not different immigration categories get access. In general, universal programs tend to be more inclusive towards immigrants, irrespective of the type of immigration category (e.g. universal traditional family programs in Portugal, Austria and France incorporate all immigrant families). By contrast, access to means-tested benefits such as social assistance depends, in most countries, on being a permanent resident or previous residence period in the host country (e.g. lone-parent programs provided in Australia and Norway). Contribution-based social programs take a middle position, as they require previous labour market participation. In sum, the approach to link immigrants' social rights to the basis of entitlement of social programs 
can be observed across advanced industrialised countries, regardless of the type of welfare regime.

\section{The impact of immigrants' social rights on poverty}

This section analyses whether immigrants' social rights in terms of both access to paid employment and social programs conditions the effect of labour market and welfare state regulations on immigrants' poverty. Starting with the labour market model, the grand-mean across countries is $35 \%$ which means that more than every third immigrant household lives with less than $50 \%$ of a country's median income. The figures range from $18 \%$ in Switzerland and Southern European countries (20-23\%), followed by Australia, Austria, Canada and the United States (all below the mean) to 52\% in Denmark, followed by Finland and the Netherlands (both above 50\%). In between are Continental European and Nordic together with Britain (all 41-46\%). Turning to labour market model using poverty based on market income only $8.3 \%$ of the variation in immigrants' poverty can be explained by country differences as the intra-class coefficient indicates (results not shown, but available upon request). Thus, individual-level determinants explain the greatest part of variation in immigrants' poverty. Better-skilled and better-educated households experience lower odds to end up in poverty. One of the strongest predictor of immigrants' pre-tax and transfer poverty is, not surprisingly, households' labour market participation. Type of employment also affects poverty. Immigrant households with atypically or self-employed individuals experience significantly higher poverty than immigrant households with standard workers employed fulltime and with an unlimited job contract (reference category). Finally, households with inactive dependents, children and elderly, are exposed to higher poverty, regardless of their age. These results support the hypothesis that socio-demographic factors, in particular skills, 
education, and employment pattern of households, are central to explaining immigrants' poverty (e.g. Brady et al., 2009; Lohman, 2009).

\section{[insert Table 1]}

Table 1 summarises the results using immigrants' poverty based on market income as the dependent variable. Model $1 \mathrm{a}$ and $1 \mathrm{~b}$ test whether immigrants' access to paid employment conditions the impact of a country's wage bargaining coordination institutions on immigrants' poverty. As both models show, wage bargaining coordination has no significant effect on immigrants' poverty. By contrast, minimum wage regulations matter. In Model 2a, the negative interaction coefficient indicates that government involvement in minimum wage setting is more effective in reducing immigrants' poverty if combined with inclusive social rights. This also seems to be the case in Model $2 \mathrm{~b}$ where the effect of minimum wage levels (in \% of median wage) on immigrant's poverty is estimated, though the interaction coefficient is not significant.

Indeed, plotting the marginal effect of minimum wage setting in Figure 4 shows that more regulated minimum wage setting increases immigrants' poverty when access to paid employment is rather restricted (see left-hand side of the graph). This effect decreases and becomes negative as immigrants' access to paid employment becomes more inclusive, but does not turn significant. In other words, more strongly regulated minimum wage setting makes a difference in countries where the barriers to enter paid employment are relatively high, by increasing their poverty, but not in countries where immigrants are granted facilitated access to the labour market by reducing their poverty, which would be in line with the hypothesis.

[insert Figure 4] 
Speaking generally, the findings support that the poverty-alleviating effect of minimum wage policies is conditional on immigrants' access to paid employment. However, a more detailed analysis reveals that is mainly the case concerning access to paid employment of labour migrants (see Model 2ai and 2bi). This finding, thus, is in line with other studies that found that minimum wage regulation is particularly important for recent immigrants because they are more likely to earn a low wage during their first years in the host country (e.g. Adsera and Chiswick, 2007). ${ }^{13}$

Turning to the welfare state model, across all countries almost every second immigrant households that were defined as poor based on market income can be lifted out of poverty when taking taxes and transfers into account. Poverty reduction scores range from less than 15 in the USA, followed by Southern European countries (18-29), Switzerland (35) and Canada (37), Greece, Portugal, to almost 82 in the Netherlands, followed by Ireland and Sweden (both around 64), the remaining Nordic countries together with France and Germany (55-59). Around the mean are Australia, Austria, Belgium and Britain. Table 2 summarises the findings on immigrants' poverty reduction. The intra-class coefficient of the benchmark model indicates that about $12.5 \%$ of the variation in immigrants' poverty reduction can be ascribed to country-level differences (results not shown). Concerning household-level characteristics, it can be said that immigrant households with lower education and skills, less earners, and atypically employed members have a higher probability to escape poverty when taxes and transfers are taken into account.

[insert Table 2]

In Model 1 the generosity of unemployment benefits interacts with immigrants' access to unemployment programs (see Table 2). The hypothesis that the effect of the generosity of unemployment programs on immigrants' poverty depends on whether they are entitled to 
unemployment programs cannot be empirically supported. But the results indicate that immigrants' access to unemployment programs reduce poverty, if net replacement rates for households with earnings $67 \%$ of the AW are at 71.8 , countries close to this grand-mean are Ireland and Italy (variables have been centred). When looking at family-related programs, the results partly support the hypothesis that its effect on immigrants' poverty depends on the inclusiveness of access to these programs. As in the unemployment benefits model, the interaction term between generosity of dual-earner programs and immigrants' access to these employment-related programs is not significant (see Model 2a). Nevertheless, the generosity of parental leave has a poverty reductive effect, at least in the countries near the grand-mean of 0.51, e.g. Norway, Switzerland and Canada.

\section{[insert Figure 5]}

By contrast, immigrants' access to traditional family benefits tend to have a povertyalleviating effect (see Model 2b). As expected, the effect of generous traditional family benefits on immigrants' poverty is stronger when immigrants' access to traditional family benefits is rather inclusive. Depicting the marginal effect of traditional family benefits in Figure 5 shows that the effect is only significant (at the 5\% level) for countries where the index values are above the mean. In other words, the generosity of traditional family benefits matters in countries where immigrants have access to these particular benefits, but has no effect in more immigrant-restrictive welfare systems. However, this poverty reducing effect can only be confirmed when the social rights of permanent residents are considered (see Model 2bi), but not for the social rights of their family members nor of labour migrants and their family members. Finally, an interaction effect between generosity of social assistance and immigrants' access cannot be empirically supported in Model 3. ${ }^{14}$ 


\section{Conclusion}

This article has shown that immigrants' social rights condition the impact of both the labour market and welfare system on immigrants' poverty: more regulated wage bargaining coordination and minimum wage policies as well as generous traditional family benefits have a greater poverty alleviating (or poverty-increasing) effect in countries with inclusive social rights towards immigrants than in countries with more exclusive social rights.

These results have important theoretical and political implications. On the one hand, this article contributes to comparative welfare state literature by demonstrating that the structure of the labour market and welfare system per se cannot explain migrant poverty. Moreover, immigrants' social rights, stratified by immigration categories, matter. Compared to citizens certain categories of immigrants do not even enjoy formal social rights in the first instance. Since immigrants have become a considerable and permanent minority in advanced industrialised countries, it is all the more important for scholars to address immigration and immigrants. On the other hand, comprehensive research exists in the international immigration literature that focuses on migration-specific characteristics and policies (see Adsera and Chiswick, 2007; Kesler, 2015; Koopmans et al., 2005; Van Tubergen et al., 2004). However, in this article I argue and empirically show that it is important to consider a country's broader institutional context together with the migration-specific context in order to understand why immigrants fare financially better in some countries as compared to others. Consequently, the main political implications of this article, at least for those concerned with poverty alleviation and immigrants' integration, is that merely introducing a practice that works in another country might not suffice. Moreover, policy makers should look at how prospective policies and regulations targeting immigrants directly (such as immigrants' social 
rights) might be embedded within a country's broader institutional setting affecting all residents.

That said, it should be emphasised that the main argument of this article is not that immigrants' social rights have a direct but a conditional impact on poverty. Thus, one reason for why wage bargaining institution and work-related social benefits have no effect might be that they do not affect all workers in the same extent. As the dualisation literature suggests, outsiders tend to be employed in specific sectors and have work contracts that are not covered by those regulations (Emmenegger et al., 2012). Even if immigrants might be put on par with non-immigrants in terms of access, as long as immigrants are overrepresented among outsiders, they might not benefit from regulations.

Another reason could be that immigrants and non-immigrants do indeed have different social rights, but are not captured by the access measure. Immigrants' right to freely choose their employment is just one aspect among others, e.g. whether immigrants have the right to equal pay, equal treatment concerning employment conditions and protection (see also Ruhs, 2013), or whether they face consequences for receiving benefits. Immigrants' legal stay and security of residence status in most host countries often depend on proof of sufficient financial means for themselves and their families (IOM 2009, Koopmans et al., 2012). Welfare dependency, at least of means-tested programs, could hence put their stay at risk. ${ }^{15}$ Consequently, even though immigrants have formal access to social programs by law, they might not use them. This could be a reason as to why there is no generosity-dependent reductive effect of social rights on immigrants' poverty for social assistance. But besides formal/legal and practised rights also the context in which these formal rights are realised is important. Even if immigrants have formal rights and use them, some immigrants might be confronted with further obstacles such as labour market discrimination that either hinder them to enter the labour market or push them to non-standard employment that have low pay, low 
employment protection and low social benefits. Future research, thus, should focus more strongly on non-institutional factors such as labour market discrimination that affect whether social rights are practiced as well as on the interplay between immigration policies, the labour market and welfare system and immigrants' social rights. 


\section{References}

Addison JT and Blackburn ML (1999) Minimum Wages and Poverty. Industrial and Labor Relations Review 52(3): 393-409.

Adsera A and Chiswick BR (2007) Are there gender and country of origin differences in immigrant labor market outcomes across European destinations? Journal of Population Economics 20(3): 495-526.

Aleinikoff TA and Klusmeyer D (2002) Citizenship Policies for an Age of Migration. Washington, DC: Carnegie Endowment for International Peace.

Armingeon K, Isler C, Knöpfel L, et al (2015) Comparative Political Data Set 1960-2013. Bern: Institute of Political Science, University of Berne.

Bäckman O (2009) Institutions, Structures and Poverty - A Comparative Study of 16 Countries, 1980-2000. European Sociological Review 25(2): 251-264.

Bäckman O and Ferrarini T (2010) Combating Child Poverty? A Multilevel Assessment of Family Policy Institutions and Child Poverty in 21 Old and New Welfare States. Journal of Social Policy 39(02): 275-296.

Banting KG and Kymlicka W (2006) Multiculturalism and the Welfare State. Recognition and Redistribution in Contemporary Democracies. Oxford: Oxford University Press.

Bassanini A and Saint-Martin A (2008) The Price of Prejudice: Labour Market Discrimination on the Grounds of Gender and Ethnicity. In: OECD (ed.) OECD Employment Outlook. Paris: OECD Publishing, pp. 139-202.

Bauer TK, Lofstrom M and Zimmermann KF (2000) Immigration Policy, Assimilation of Immigrants and Natives' Sentiments towards Immigrants: Evidence from 12 OECD-countries. Swedish Economic Policy Review 7(2): 11-53.

Betcherman G (2012) Labor Market Institutions. A Review of the Literature. Policy Research Working Paper 6276.

Bloemraad I, Korteweg A and Yurdakul G (2008) Citizenship and Immigration: Multiculturalism, Assimilation, and Challenges to the Nation-State. Annual Review of Sociology 34(1): 153-179.

Borjas GJ and Hilton L (1996) Immigration and the Welfare State: Immigrant Participation in Means-Tested Entitlement Programs. The Quarterly Journal of Economics 111(2): 575-604.

Brady D (2009) Rich Democracies, Poor People. How Politics Explain Poverty. Oxford: Oxford University Press. 
Brady D, Fullerton AS and Cross JM (2009) Putting Poverty in Political Context: A Multi-Level Analysis of Adult Poverty across 18 Affluent Democracies. Social Forces 88(1): 271-299.

Brubaker R (1989) Membership without Citizenship: the Economic and Social Rights of Noncitizens. In: Brubaker R (ed). Immigration and the Politics of Citizenship in Europe and North America. Lanham: University Press of America, pp. 145-162.

Cantillon B (2011) The paradox of the social investment state: growth, employment and poverty in the Lisbon era. Journal of European Social Policy 21(5): 432-449.

Corrigan O (2014) Migrant deprivation, conditionality of legal status and the welfare state. Journal of European Social Policy 24(3): 223-239.

Dancygier RM and Laitin DD (2014) Immigration into Europe: Economic Discrimination, Violence, and Public Policy. Annual Review of Political Science 17(1): 43-64.

Eichhorst W and Marx P (2012) Whatever Works: Dualization and the Service Economy in Bismarckian Welfare States. In: Emmenegger P, Häusermann S, Palier B, et al (eds) The Age of Dualization. Oxford: Oxford University Press, pp. 73-99.

Emmenegger P, Häusermann S, Palier B, et al (2012) The Age of Dualization., Oxford: Oxford University Press. Esping-Andersen G (1990) Three Worlds of Welfare Capitalism. Princeton: Princeton University Press.

Esping-Andersen G (1999) Social Foundations of Postindustrial Economies. Oxford: Oxford University Press. Freeman GP (2004) Immigrant Incorporation in Western Democracies. International Migration Review 38(3): 945-969.

Gornick JC, Meyers MK and Ross KE (1997) Supporting the Employment of Mothers: Policy Variation across Fourteen Welfare States. Journal of European Social Policy 7(1): 45-70.

Gundersen C and Ziliak JP (2004) Poverty and Macroeconomic Performance across Space, Race, and Family Structure. Demography 41(1): 61-86.

Hammar T (1985) European Immigration Policy: A Comparative Study. Cambridge: Cambridge University Press.

Hammar T (1990) Democracy and the Nation State. Aliens, Denizens and Citizens in a World of International Migration. Aldershot: Avebury.

Hanushek EA, Woessmann L and Zhang L (2017) General Education, Vocational Education, and Labor-Market Outcomes Over the Life-Cycle. The Journal of Human Resources 52(1): 48-87. 
Häusermann S and Schwander H (2012) Varieties of Dualization. Labor Market Segmentation and InsiderOutsider Divides Across Regimes. In: Emmenegger P, Häusermann S, Palier B, et al (eds) The Age of Dualization. Oxford: Oxford University Press, pp. 27-51.

Helbling M, Bjerre L, Römer F, et al (2016) Measuring Immigration Policies: The IMPIC Database. European Political Science: 1-37.

Huber E and Stephens JD (2001) Development and Crisis of the Welfare State. Parties and Policies in Global Markets. Chicago and London: The University of Chicago Press.

Huddleston T, Niessen J, Ni Chaoimh E, et al (2011) Migrant Integration Policy Index III. Brussels: British Council and Migration Policy Group.

IOM (2009) Comparative study of the laws in the 27 EU member states for legal immigration. Including an assessment of the conditions and formalities imposed by each member state for newcomers. Geneva: International Organization for Migration.

Kalter F and Kogan I (2014) Migrant networks and labor market integration of immigrants from the former Soviet Union in Germany. Social Forces 92(4): 1435-1456.

Kenworthy L (2001) Wage-Setting Measures: A Survey and Assessment. World Politics 54(1): 57-98.

Kenworthy L (2011) Progress for the Poor. Oxford: Oxford University Press.

Kesler C (2015) Welfare states and immigrant poverty: Germany, Sweden, and the United Kingdom in comparative perspective. Acta Sociologica 58(1): 39-61.

Koopmans R, Michalowski I and Waibel S (2012) Citizenship rights for immigrants: national political processes and cross-national convergence in western Europe, 1980-2008. American Journal of Sociology 117(4): 12021245.

Koopmans R, Statham P, Giugni M, et al (2005) Contested Citizenship. Immigration and Cultural Diversity in Europe. Minneapolis: University of Minnesota Press.

Korpi W and Palme J (1998) The Paradox of Redistribution and Strategies of Equality: Welfare State Institutions, Inequality, and Poverty in the Western Countries. American Sociological Review 63(5): 661687.

Layton-Henry Z (1990) The Political Rights of Migrant Workers in Western Europe. London: Sage.

Lohmann H (2009) Welfare States, Labour Market Institutions and the Working Poor: A Comparative Analysis of 20 European Countries. European Sociological Review 25(4): 489-504. 
Marchal S, Marx I and Van Mechelen N (2014) The Great Wake-Up Call? Social Citizenship and Minimum Income Provisions in Europe in Times of Crisis. Journal of Social Policy 43(2): 247-267.

Marx I, Salanauskaite L and Verbist G (2013) The Paradox of Redistribution Revisited: And That It May Rest in Peace? Discussion Paper Series IZA DP No. 7414.

MISSOC - Mutual Information System on Social Protection (2007) MISSOC Comparative Tables Database. Available at: http://www.missoc.org/MISSOC/INFORMATIONBASE/COMPARATIVETABLES/MISSOCDATABASE/ comparativeTableSearch.jsp (accessed 25 May 2012).

Misra J, Moller S and Budig MJ (2007) Work-Family Policies and Poverty for Partnered and Single Women in Europe and North America. Gender \& Society 21(6): 804-827.

Misra J, Moller S, Strader E, et al (2012) Family policies, employment and poverty among partnered and single mothers. Research in Social Stratification and Mobility 30(1): 113-128.

Moller S, Huber E, Stephens JD, et al (2003) Determinants of Relative Poverty in Advanced Capitalist Democracies. American Journal of Sociology 68(1): 22-51.

Morris L (2003) Managing Contradiction: Civic Stratification and Migrants' Rights. International Migration Review 37(1): 74-100.

Nelson K (2007) Introducing SaMip: The Social Assistance and Minimum Income Protection Interim Dataset. SWoPEc No. 11/2007. Swedish Institute for Social Research.

OECD (1998) Employment Outlook 1998. Paris: OECD Publishing.

OECD (2007) Benefits and Wages: Country specific information. Paris: OECD Publishing.

OECD (2009) International Migration Outlook. SOPEMI 2009. Special Focus: Managing Labour Migration Beyond the Crisis. Paris: OECD Publishing.

OECD (2015a) In it together. Why less inequality benefits all, Paris: OECD Publishing.

OECD (2015b) OECD.Stat. Available at: http://stats.oecd.org (accessed 30 September 2015).

OECD (2015c) Indicators of Immigrant Integration 2015. Settling in. Paris: OECD Publishing.

Orloff A (1993) Gender and the Social Rights of Citizenship: the Comparative Analysis of Gender Relations and Welfare States. American Sociological Review 58(2): 303-328. 
Pager D and Shepherd H (2008) The Sociology of Discrimination: Racial Discrimination in Employment, Housing, Credit, and Consumer Markets. Annual Review of Sociology 34: 181-209.

Pontusson J, Rueda D and Way CR (2002) Comparative Political Economy of Wage Distribution: The Role of Partisanship and Labour Market Institutions. British Journal of Political Science 32: 281-308.

Rabe-Hesketh S and Skrondal A (2012) Multilevel and Longitudinal Modeling Using Stata, 3rd edition, College Station. Texas: Stata Press.

Ruhs M (2013) The Price of Rights: Regulating International Labor Migration. Princeton, NJ: Princeton University Press.

Sainsbury D (2006) Immigrants' social rights in comparative perspective: welfare regimes, forms of immigration and immigration policy regimes. Journal of European Social Policy 16(3): 361-380.

Sainsbury D (2012) Welfare States and Immigrant Rights. The Politics of Inclusion and Exclusion. Oxford: Oxford University Press.

Sainsbury D and Morissens A (2002) Journal of European Social Policy. Journal of European Social Policy 12(4): 307-327.

Scruggs L and Allan JP (2006) The Material Consequences of Welfare States: Benefit Generosity and Absolute Poverty in 16 OECD Countries. Comparative 39(7): 800-904.

Snijders TA and Bosker RJ (2012) Multilevel Analysis, 2nd edition. London: Sage.

Soysal YN (1994) Limits of Citizenship. Migrants and Postnational Membership in Europe. Chicago and London: The University of Chicago Press.

Van Lancker W (2014) To whose benefit? An empirical and comparative investigation into the (un)intended consequences of family policy in the social investment state. Brussels: University Press Antwerp.

Van Tubergen F, Maas I and Flap H (2004) The Economic Incorporation of Immigrants in 18 Western Societies: Origin, Destination, and Community Effects. American Sociological Review 69(5): 704-727.

Visser J (2013) CTWSS Database, Database on Institutional Characteristics of Trade Unions, Wage Setting, State Intervention and Social Pacts in 34 countries between 1960 and 2010. Amsterdam: Institute for Advanced Labour Studies, AIAS, University of Amsterdam.

Wallerstein M (1999) Institutions and Pay Inequality in Advanced Industrial Societies. American Journal of Political Science 43(3): 649-680. 
Table 1. Determinants of immigrants' poverty based on market income.

\begin{tabular}{|c|c|c|c|c|c|c|}
\hline & Model 1a & Model 1b & Model 2a & $\begin{array}{c}\text { Model 2ai } \\
\text { (labour } \\
\text { migrants) }\end{array}$ & Model 2b & $\begin{array}{c}\text { Model 2bi } \\
\text { (labour } \\
\text { migrants }\end{array}$ \\
\hline \multirow[t]{2}{*}{ GDP growth (5-year average) } & 0.193 & 0.209 & 0.074 & 0.129 & 0.150 & 0.220 \\
\hline & $(0.15)$ & $(0.15)$ & $(0.15)$ & $(0.16)$ & $(0.17)$ & $(0.14)$ \\
\hline \multirow[t]{2}{*}{ Industrialised countries, \% foreign born } & -0.001 & -0.011 & -0.003 & -0.008 & -0.012 & $-0.017+$ \\
\hline & $\begin{array}{l}(0.01) \\
0.232\end{array}$ & $\begin{array}{l}(0.01) \\
-0.219\end{array}$ & $\begin{array}{r}(0.01) \\
0.299\end{array}$ & $(0.01)$ & $\begin{array}{l}(0.01) \\
-0.299\end{array}$ & $(0.01)$ \\
\hline Index labour market (paid employment) & $\begin{array}{l}0.232 \\
(1.10)\end{array}$ & $\begin{array}{l}-0.219 \\
(1.17)\end{array}$ & $\begin{array}{l}0.299 \\
(0.98)\end{array}$ & & $\begin{array}{l}-0.299 \\
(1.06)\end{array}$ & \\
\hline Wage bargaining coordination & $\begin{array}{l}-0.053 \\
(0.11)\end{array}$ & & & & & \\
\hline Wage bargaining coordination $\mathrm{X}$ access (emp.) & $\begin{array}{l}1.489 \\
(0.92)\end{array}$ & & & & & \\
\hline Government intervention & & $\begin{array}{l}-0.179 \\
(0.12)\end{array}$ & & & & \\
\hline Government intervention X access (emp.) & & $\begin{array}{l}-0.881 \\
(1.38)\end{array}$ & & & & \\
\hline Minimum wage setting & & & $\begin{array}{l}0.030 \\
(0.04)\end{array}$ & $\begin{array}{l}0.022 \\
(0.04)\end{array}$ & & \\
\hline Minimum wage setting $X$ access (emp.) & & & $\begin{array}{c}-0.833^{*} \\
(0.34)\end{array}$ & $\begin{array}{c}-0.567^{*} \\
(0.25)\end{array}$ & & \\
\hline Minimum wage (\% of median) & & & & & $\begin{array}{l}0.001 \\
(0.01)\end{array}$ & $\begin{array}{l}0.001 \\
(0.00)\end{array}$ \\
\hline Minimum wage $X$ access (emp.) & & & & & $\begin{array}{c}-0.076 \\
(0.05)\end{array}$ & $\begin{array}{c}-0.064^{*} \\
(0.03)\end{array}$ \\
\hline Constant & $\begin{array}{c}2.776^{* * *} \\
(0.17)\end{array}$ & $\begin{array}{c}2.762^{* * *} \\
(0.17)\end{array}$ & $\begin{array}{c}2.748^{* * *} \\
(0.16)\end{array}$ & $\begin{array}{c}2.785^{* * *} \\
(0.16)\end{array}$ & $\begin{array}{c}2.782^{* * *} \\
(0.17)\end{array}$ & $\begin{array}{c}2.838^{* * *} \\
(0.16)\end{array}$ \\
\hline Intercept & $\begin{array}{c}-0.768^{* * *} \\
(0.18)\end{array}$ & $\begin{array}{c}-0.751^{* * *} \\
(0.18)\end{array}$ & $\begin{array}{c}-0.852^{* * *} \\
(0.18)\end{array}$ & $\begin{array}{c}-0.875^{* * *} \\
(0.19)\end{array}$ & $\begin{array}{c}-0.759 * * * \\
(0.18)\end{array}$ & $\begin{array}{c}-0.873^{* * *} \\
(0.19)\end{array}$ \\
\hline Var (countries) & 0.215 & 0.223 & 0.182 & 0.174 & 0.219 & 0.174 \\
\hline Intra-class correlation & 0.061 & 0.063 & 0.052 & 0.050 & 0.063 & 0.050 \\
\hline Log-likelihood & -5764.945 & -5765.157 & -5763.534 & -5763.326 & -5765.026 & -5763.280 \\
\hline LR test & 140.468 & 163.433 & 116.832 & 90.603 & 161.848 & 95.998 \\
\hline N (households) & 15150 & 15150 & 15150 & 15150 & 15150 & 15150 \\
\hline $\mathrm{N}$ (countries) & 19 & 19 & 19 & 19 & 19 & 19 \\
\hline
\end{tabular}

Notes: Standard errors in parentheses. ${ }^{+} p<0.10,{ }^{*} p<0.05,{ }^{* *} p<0.01,{ }^{* * *} p<0.001$. 
Table 2. Determinants of immigrants' poverty reduction.

\begin{tabular}{|c|c|c|c|c|c|}
\hline & Model 1 & Model 2a & Model 2b & $\begin{array}{c}\text { Model } 2 \mathrm{bi} \\
\text { (permanent } \\
\text { residents) }\end{array}$ & Model 3 \\
\hline GDP growth (5-year average) & $\begin{array}{l}-0.071 \\
(0.19)\end{array}$ & $\begin{array}{c}0.266+ \\
(0.16)\end{array}$ & $\begin{array}{l}0.157 \\
(0.18)\end{array}$ & $\begin{array}{c}0.271+ \\
(0.15)\end{array}$ & $\begin{array}{l}0.346 \\
(0.24)\end{array}$ \\
\hline Industrialised countries, \% foreign born & $\begin{array}{l}0.007 \\
(0.01)\end{array}$ & $\begin{array}{l}0.006 \\
(0.01)\end{array}$ & $\begin{array}{l}-0.004 \\
(0.01)\end{array}$ & $\begin{array}{c}-0.022^{*} \\
(0.01)\end{array}$ & $\begin{array}{l}-0.019 \\
(0.02)\end{array}$ \\
\hline Index access (unemployment) & $\begin{array}{c}3.233^{* *} \\
(1.08)\end{array}$ & & & & \\
\hline Unemployment programs (generosity) & $\begin{array}{l}1.558 \\
(1.22)\end{array}$ & & & & \\
\hline Unemployment programs X access (progr.) & $\begin{array}{l}-3.671 \\
(12.83)\end{array}$ & & & & \\
\hline Index access (dual-earner) & & $\begin{array}{l}-0.326 \\
(0.62)\end{array}$ & & & \\
\hline Dual-earner programs (generosity) & & $\begin{array}{c}0.029 * * * \\
(0.01)\end{array}$ & & & \\
\hline Dual-earner programs $X$ access (progr.) & & $\begin{array}{r}-0.000 \\
(0.03)\end{array}$ & & & \\
\hline Index access (traditional family benefits) & & & $\begin{array}{l}1.770^{*} \\
(0.70)\end{array}$ & $\begin{array}{c}3.076^{* * *} \\
(0.74)\end{array}$ & \\
\hline Traditional family benefits (generosity) & & & $\begin{array}{r}0.074^{*} \\
(0.03)\end{array}$ & $\begin{array}{c}0.053^{*} \\
(0.03)\end{array}$ & \\
\hline Trad. family benefits $X$ access (progr.) & & & $\begin{array}{l}0.203^{*} \\
(0.10)\end{array}$ & $\begin{array}{l}0.218^{*} \\
(0.08)\end{array}$ & \\
\hline Index access (social assistance) & & & & & $\begin{array}{l}0.144 \\
(0.52)\end{array}$ \\
\hline Social assistance (generosity) & & & & & $\begin{array}{l}0.025 \\
(0.02)\end{array}$ \\
\hline Social assistance $X$ access (progr.) & & & & & $\begin{array}{r}-0.060 \\
(0.05)\end{array}$ \\
\hline Constant & $\begin{array}{c}-0.665^{* * *} \\
(0.16)\end{array}$ & $\begin{array}{c}-0.673^{* * *} \\
(0.16)\end{array}$ & $\begin{array}{c}-0.638^{* * *} \\
(0.16)\end{array}$ & $\begin{array}{c}-0.702^{* * *} \\
(0.15)\end{array}$ & $\begin{array}{c}-0.538^{* *} \\
(0.19)\end{array}$ \\
\hline Intercept & $\begin{array}{c}-0.753^{* * *} \\
(0.19)\end{array}$ & $\begin{array}{c}-0.859^{* * *} \\
(0.20)\end{array}$ & $\begin{array}{c}-0.714^{* * *} \\
(0.19)\end{array}$ & $\begin{array}{c}-0.911^{* * *} \\
(0.20)\end{array}$ & $\begin{array}{c}-0.592^{* *} \\
(0.19)\end{array}$ \\
\hline $\mathrm{N}$ (households) & 15150 & 15150 & 15150 & 15150 & 14891 \\
\hline $\mathrm{N}$ (countries) & 19 & 19 & 19 & 19 & 18 \\
\hline LR test & 102.065 & 66.262 & 102.552 & 74.883 & 167.302 \\
\hline Intra-class correlation & 0.063 & 0.052 & 0.068 & 0.047 & 0.085 \\
\hline Var (countries) & 0.222 & 0.179 & 0.240 & 0.162 & 0.306 \\
\hline Log-likelihood & -3713.109 & -3711.382 & -3713.701 & -3710.343 & -3665.220 \\
\hline
\end{tabular}




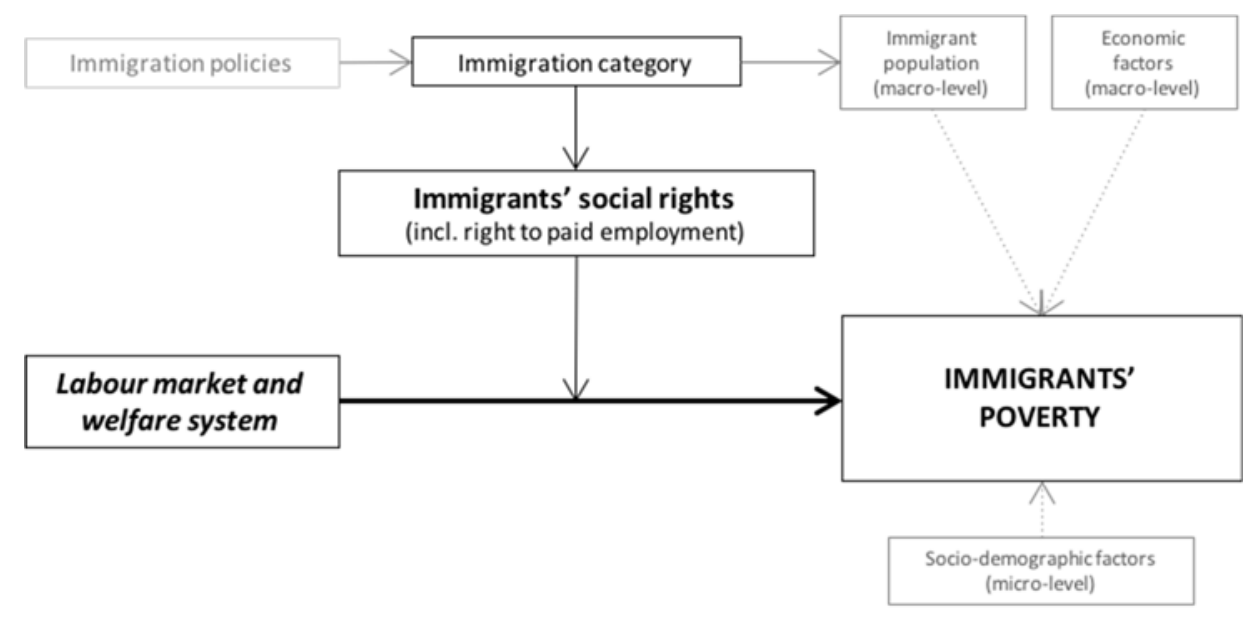

Figure 1. Framework 


\section{Index access to paid employment}

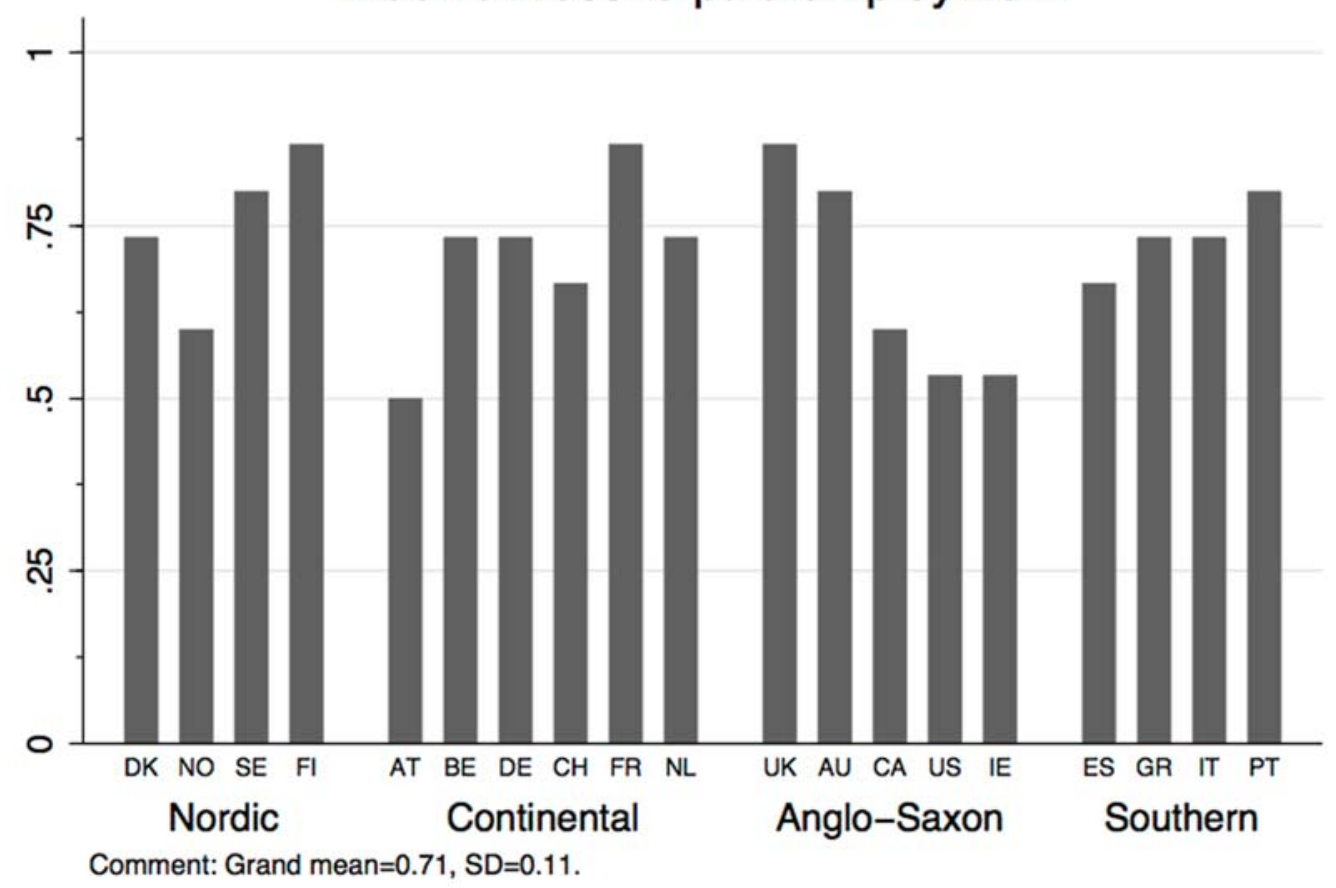

Figure 2. Index immigrants' access to paid employment. 
Unemployment programs

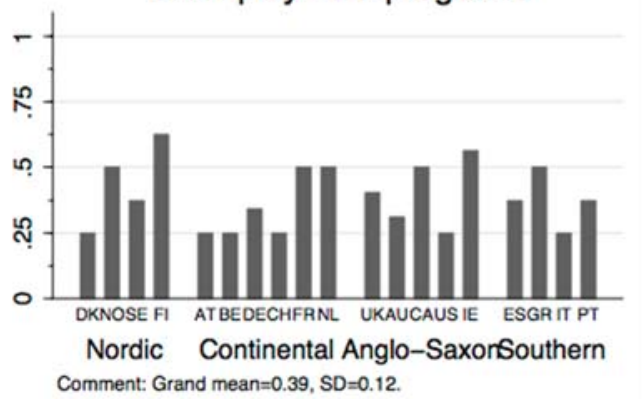

Traditional family benefits

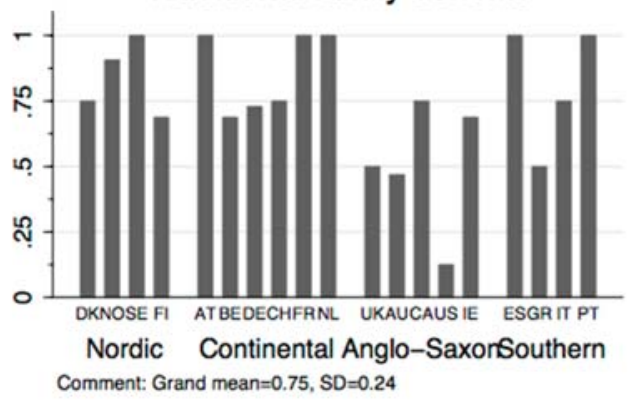

Dual-earner programs

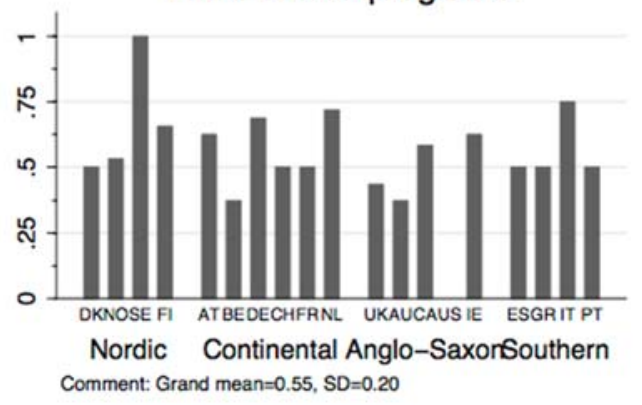

Social assistance

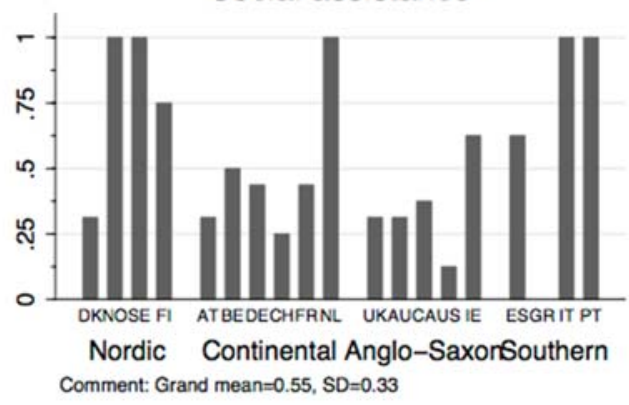

Figure 3. Indices immigrants' access to social programs. 


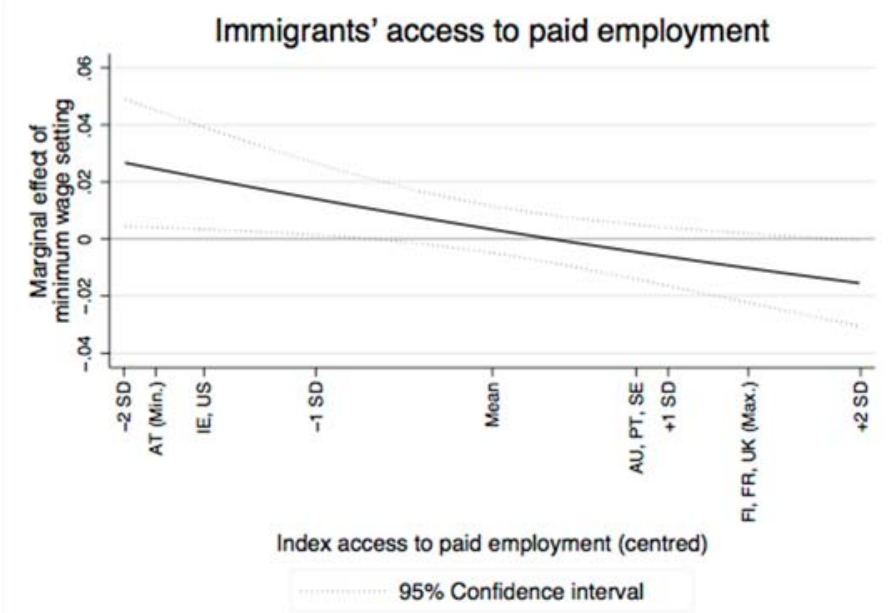

Figure 4. Marginal effect of minimum wage setting on immigrants' poverty based on market income. 


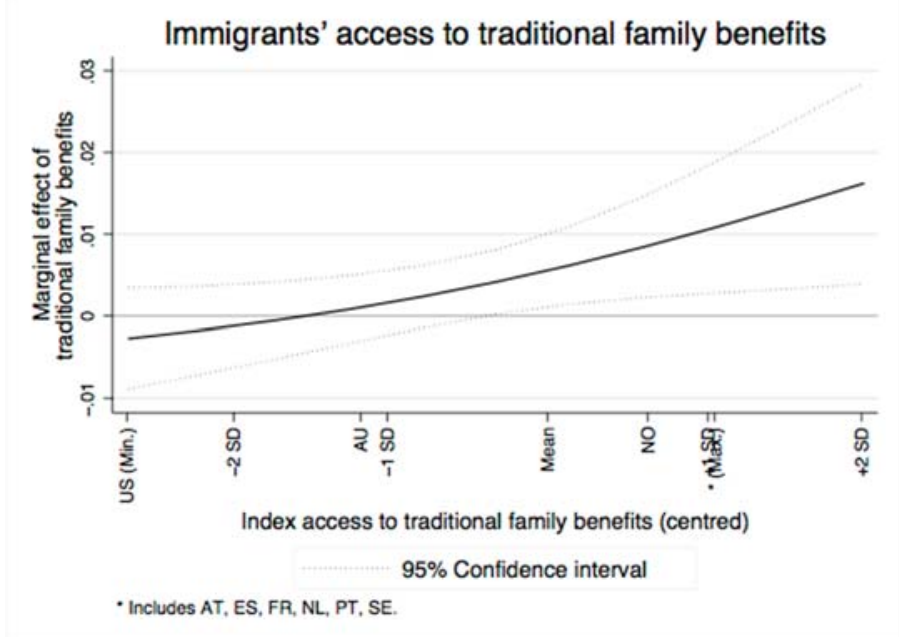

Figure 5. Marginal effect of traditional family benefits on immigrants' poverty reduction. 
Table 1. Determinants of immigrants' poverty based on market income.

\begin{tabular}{|c|c|c|c|c|c|c|}
\hline & Model 1a & Model 1b & Model 2a & $\begin{array}{l}\text { Model 2ai } \\
\text { (labour } \\
\text { migrants) }\end{array}$ & Model 2b & $\begin{array}{l}\text { Model 2bi } \\
\text { (labour } \\
\text { migrants }\end{array}$ \\
\hline \multirow{2}{*}{$\begin{array}{l}\text { GDP growth (5-year } \\
\text { average) }\end{array}$} & 0.193 & 0.209 & 0.074 & 0.129 & 0.150 & 0.220 \\
\hline & $(0.15)$ & $(0.15)$ & (0.15) & $(0.16)$ & $(0.17)$ & $(0.14)$ \\
\hline \multirow{2}{*}{$\begin{array}{l}\text { Industrialised countries, } \\
\% \text { foreign born }\end{array}$} & -0.001 & -0.011 & -0.003 & -0.008 & -0.012 & $-0.017^{+}$ \\
\hline & $(0.01)$ & $(0.01)$ & $(0.01)$ & $(0.01)$ & $(0.01)$ & $(0.01)$ \\
\hline \multirow{2}{*}{$\begin{array}{l}\text { Index labour market } \\
\text { (paid employment) }\end{array}$} & 0.232 & -0.219 & 0.299 & & -0.299 & \\
\hline & (1.10) & (1.17) & (0.98) & & $(1.06)$ & \\
\hline \multirow{2}{*}{$\begin{array}{l}\text { Wage bargaining } \\
\text { coordination }\end{array}$} & -0.053 & & & & & \\
\hline & $(0.11)$ & & & & & \\
\hline \multirow{2}{*}{$\begin{array}{l}\text { Wage bargaining } \\
\text { coordination } X \text { access } \\
\text { (emp.) }\end{array}$} & 1.489 & & & & & \\
\hline & $(0.92)$ & & & & & \\
\hline Government & & -0.179 & & & & \\
\hline intervention & & $(0.12)$ & & & & \\
\hline Government & & -0.881 & & & & \\
\hline $\begin{array}{l}\text { intervention } \mathrm{X} \text { access } \\
\text { (emp.) }\end{array}$ & & $(1.38)$ & & & & \\
\hline \multirow[t]{2}{*}{ Minimum wage setting } & & & 0.030 & 0.022 & & \\
\hline & & & $(0.04)$ & $(0.04)$ & & \\
\hline \multirow{2}{*}{$\begin{array}{l}\text { Minimum wage setting } \\
X \text { access (emp.) }\end{array}$} & & & $-0.833^{*}$ & $-0.567^{*}$ & & \\
\hline & & & $(0.34)$ & $(0.25)$ & & \\
\hline \multirow{2}{*}{$\begin{array}{l}\text { Minimum wage (\% of } \\
\text { median) }\end{array}$} & & & & & 0.001 & 0.001 \\
\hline & & & & & $(0.01)$ & $(0.00)$ \\
\hline \multirow{2}{*}{$\begin{array}{l}\text { Minimum wage } X \text { access } \\
\text { (emp.) }\end{array}$} & & & & & -0.076 & $-0.064 *$ \\
\hline & & & & & $(0.05)$ & $(0.03)$ \\
\hline \multirow[t]{2}{*}{ Constant } & $2.776 * * *$ & $2.762 * * *$ & $2.748 * * *$ & $2.785^{* * *}$ & $2.782 * * *$ & $2.838^{* * *}$ \\
\hline & $(0.17)$ & $(0.17)$ & $(0.16)$ & $(0.16)$ & $(0.17)$ & $(0.16)$ \\
\hline \multirow[t]{2}{*}{ Intercept } & $-0.768 * * *$ & $-0.751 * * *$ & $-0.852 * * *$ & $-0.875^{* * *}$ & $-0.759 * * *$ & $-0.873 * * *$ \\
\hline & $(0.18)$ & $(0.18)$ & $(0.18)$ & $(0.19)$ & $(0.18)$ & (0.19) \\
\hline Var (countries) & 0.215 & 0.223 & 0.182 & 0.174 & 0.219 & 0.174 \\
\hline Intra-class correlation & 0.061 & 0.063 & 0.052 & 0.050 & 0.063 & 0.050 \\
\hline Log-likelihood & -5764.945 & -5765.157 & -5763.534 & -5763.326 & -5765.026 & -5763.280 \\
\hline LR test & 140.468 & 163.433 & 116.832 & 90.603 & 161.848 & 95.998 \\
\hline $\mathrm{N}$ (households) & 15150 & 15150 & 15150 & 15150 & 15150 & 15150 \\
\hline $\mathrm{N}$ (countries) & 19 & 19 & 19 & 19 & 19 & 19 \\
\hline
\end{tabular}

GDP: gross domestic product; LR: likelihood ratio.

Coefficients (log odds) of random intercept logit models, standard errors in parentheses. All models are estimated including householdlevel variables (not shown).

$+p<0.10 ;{ }^{*} p<0.05 ; * *<0.01 ; * * p<0.001$. 
Table 2. Determinants of immigrants' poverty reduction.

\begin{tabular}{|c|c|c|c|c|c|}
\hline & Model 1 & Model 2a & Model 2b & $\begin{array}{l}\text { Model } 2 \mathrm{bi} \\
\text { (permanent } \\
\text { residents) }\end{array}$ & Model 3 \\
\hline GDP growth (5-year average) & $\begin{array}{l}-0.071 \\
(0.19)\end{array}$ & $\begin{array}{l}0.266^{\dagger} \\
(0.16)\end{array}$ & $\begin{array}{l}0.157 \\
(0.18)\end{array}$ & $\begin{array}{c}0.271^{\dagger} \\
(0.15)\end{array}$ & $\begin{array}{l}0.346 \\
(0.24)\end{array}$ \\
\hline $\begin{array}{l}\text { Industrialised countries, \% foreign } \\
\text { born }\end{array}$ & $\begin{array}{l}0.007 \\
(0.01)\end{array}$ & $\begin{array}{l}0.006 \\
(0.01)\end{array}$ & $\begin{array}{l}-0.004 \\
(0.01)\end{array}$ & $\begin{array}{c}-0.022^{*} \\
(0.01)\end{array}$ & $\begin{array}{l}-0.019 \\
(0.02)\end{array}$ \\
\hline Index access (unemployment) & $\begin{array}{c}3.233^{* *} \\
(1.08)\end{array}$ & & & & \\
\hline $\begin{array}{l}\text { Unemployment programs } \\
\text { (generosity) }\end{array}$ & $\begin{array}{l}1.558 \\
(1.22)\end{array}$ & & & & \\
\hline $\begin{array}{l}\text { Unemployment programs } X \text { access } \\
\text { (progr.) }\end{array}$ & $\begin{array}{l}-3.671 \\
(12.83)\end{array}$ & & & & \\
\hline Index access (dual-earner) & & $\begin{array}{l}-0.326 \\
(0.62)\end{array}$ & & & \\
\hline Dual-earner programs (generosity) & & $\begin{array}{c}0.029 * * * \\
(0.01)\end{array}$ & & & \\
\hline $\begin{array}{l}\text { Dual-earner programs } X \text { access } \\
\text { (progr.) }\end{array}$ & & $\begin{array}{l}-0.000 \\
(0.03)\end{array}$ & & & \\
\hline $\begin{array}{l}\text { Index access (traditional family } \\
\text { benefits) }\end{array}$ & & & $\begin{array}{l}1.770^{*} \\
(0.70)\end{array}$ & $\begin{array}{c}3.076 * * * \\
(0.74)\end{array}$ & \\
\hline $\begin{array}{l}\text { Traditional family benefits } \\
\text { (generosity) }\end{array}$ & & & $\begin{array}{c}0.074 * \\
(0.03)\end{array}$ & $\begin{array}{l}0.053 * \\
(0.03)\end{array}$ & \\
\hline $\begin{array}{l}\text { Trad. family benefits } X \text { access } \\
\text { (progr.) }\end{array}$ & & & $\begin{array}{l}0.203^{*} \\
(0.10)\end{array}$ & $\begin{array}{l}0.218^{*} \\
(0.08)\end{array}$ & \\
\hline Index access (social assistance) & & & & & $\begin{array}{l}0.144 \\
(0.52)\end{array}$ \\
\hline Social assistance (generosity) & & & & & $\begin{array}{l}0.025 \\
(0.02)\end{array}$ \\
\hline Social assistance $X$ access (progr.) & & & & & $\begin{array}{l}-0.060 \\
(0.05)\end{array}$ \\
\hline Constant & $\begin{array}{c}-0.665^{* * *} \\
(0.16)\end{array}$ & $\begin{array}{c}-0.673^{* * *} \\
(0.16)\end{array}$ & $\begin{array}{c}-0.638^{* * *} \\
(0.16)\end{array}$ & $\begin{array}{c}-0.702^{* * *} \\
(0.15)\end{array}$ & $\begin{array}{c}-0.538^{* *} \\
(0.19)\end{array}$ \\
\hline Intercept & $\begin{array}{c}-0.753^{* * *} \\
(0.19)\end{array}$ & $\begin{array}{c}-0.859 * * * \\
(0.20)\end{array}$ & $\begin{array}{c}-0.714^{* * *} \\
(0.19)\end{array}$ & $\begin{array}{c}-0.911^{* * *} \\
(0.20)\end{array}$ & $\begin{array}{c}-0.592^{* *} \\
(0.19)\end{array}$ \\
\hline Var (countries) & 0.222 & 0.179 & 0.240 & 0.162 & 0.306 \\
\hline Intra-class correlation & 0.063 & 0.052 & 0.068 & 0.047 & 0.085 \\
\hline Log-likelihood & -3713.109 & -3711.382 & -3713.701 & -3710.343 & -3665.220 \\
\hline LR test & 102.065 & 66.262 & 102.552 & 74.883 & 167.302 \\
\hline N (households) & 15150 & 15150 & 15150 & 15150 & 14891 \\
\hline N (countries) & 19 & 19 & 19 & 19 & 18 \\
\hline
\end{tabular}

GDP: gross domestic product; LR: likelihood ratio.

Coefficients (log odds) of random intercept logit models, standard errors in parentheses. All models are estimated including householdlevel variables (not shown).

$+p<0.10 ;{ }^{*} p<0.05 ; * p<0.01 ; * * p<0.001$ 
1 Permanent residents are also considered as immigration policies affect them until they become naturalised citizens (see Hammar, 1990).

2 However, states cannot fully control their borders. Immigrants might reside illegally in a country by crossing borders unlawfully or overstaying their visa permits. Moreover, family reunification as a human right set out in international conventions limits the scope of governments to restrain the inflow of family members.

3 More detailed research found that differences regarding the access to social services exist even between citizens and permanent residents (Aleinikoff and Klusmeyer, 2002; Sainsbury, 2006).

4 Migrant networks, for instance, not only provide information on procedures and employment opportunities for migrant job seekers but also might help recruiting employers concerning uncertainties related to job qualifications and skills of migrant applicants and thus contribute to reduce labour market discrimination. However, it is debated whether migrant networks are only beneficial for migrants' socio-economic situation. In the long-run they might hinder mobility and lead to "entrapment", often in low-wage sector of the economy (see Kalter and Kogan, 2014).

5 The year 2007 has been selected to consider the situation before the outbreak of the financial crisis, which has hit immigrants particularly hard (OECD, 2009) and gave rise to consequential policy responses (see Marshal et al., 2014).

6 Unfortunately, the income surveys do not provide detailed information on the immigrant background such as type of residence permit which would allow to identify immigrants by immigration categories (e.g. EU-SILC only provides two indicators referring the place of birth and citizenship each with three categories referring to the country of residence, the EU or other countries). For this reason and the low number of immigrants in the sample, I rely on the crude proxy whether the respondent is born in the place of residence or not, though this represents a clear limitation in the data.

7 Consequently, single income components are used whenever possible to calculate market and disposable household income. However, the aggregated survey income variables were used when the replication of these variables using single income components was not possible, e.g. due to topcoding and imputations (HILDA and SLID). Thus, the Canadian market income includes "other taxable income" and alimonies (excluding both components yields comparable results concerning direction and significance levels of the coefficients). But comparability is also complicated when using single income components. Some countries in the EU-SILC 
survey such as Greece and Italy only report income (or only single income components, e.g. Spain and Portugal) net of taxes and social contributions (e.g. Greece and Italy; for France and Netherlands income is net of social contributions). In addition to differences in reporting income components, imputation practices and minimum age of respondents (15 years in the HILDA and CPS, 16 years in the SLID and EU-SILC surveys), the surveys also vary regarding household definitions. For non-European surveys, I choose the income units that come closest to the EU-SILC household definition as persons living together in a private dwelling and - most importantly - sharing expenditures (e.g. economic families in the SLID survey rather than households).

8 The models have also been calculated using the European Union's official poverty line set at $60 \%$ of the national median income.

9 Using the ISCED level as a determinant of poverty might be problematic as they cannot appropriately mirror educational credentials in countries with a dual apprenticeship system (e.g. Germany, Austria, Denmark, Switzerland). In these countries apprentice, i.e. a medium ISCED level, might ensure good employment opportunities and decent wages, although recent research shows that the initial advantage of vocational education as opposed to general education diminishes with age (Hanushek et al., 2017).

10 Although irregular immigrants are an issue in political debates, this analysis does not include their social rights as a separate immigration category as legal residence is a relatively explicit requirement to access social programs focused on in this article.

${ }^{11}$ All models have been estimated using xtmelogit in Stata 14.

12 Of course, countries can implement a range of different labour immigration programs (see also Ruhs, 2013, Appendix 1, Table A3: 203ff.). Here, the general trends are discussed.

${ }^{13}$ Using the higher European Union's official poverty line does not alter the direction of the coefficients but the level of significance in the labour migrant models (Model 2ai and 2bi: $\mathrm{p}<0.1$ ). Moreover, the main findings do not change when controlling for labour market discrimination using indicators such as prejudice against migrants (based on the question how many respondents mentioned they do not like to have migrants/foreign workers as neighbours, see WVS, 2014), overqualification rates of 15-64 highly educated foreign-born workers (OECD, 2015c: 117), share of foreign-born employment and share of immigrant employment in lowskilled occupations (OECD, 2009: 88).

${ }_{14}$ Again, the direction of the coefficients does not change when using the European Union's official poverty line but the level of significance in the "general immigrant" model (Model 2b: $\mathrm{p}<0.1$ ). 
${ }^{15}$ Discretionary practices by bureaucracies and administrative bodies, or simply immigrants' lack of knowledge concerning their social rights could be alternative explanations. For instance, Borjas and Hilton (1996: 596f.) explain differences in immigrant nationalities' welfare use by ethnic network communities, through which information about specific programs is passed to newly arrived immigrants. 